\title{
LASIK CLINIC NEW BUSINESS MODEL TO MEET THE SURGICAL COST CHALLENGES: A CONTRIBUTION TO DECREASE INDONESIA'S REFRACTIVE DISORDERS RATE AND TO MEET INDONESIA'S HEALTHY VISION OF 2020
}

\author{
Pujiastuti Sophia, Yanuar R.S. Tantri, Pusaka Semerdanta, Indrawati Ratna \\ Faculty of Economic and Business, University of Esa Unggul, Indonesia \\ *E-mail: sophi p@silclasik@gmail.com
}

\begin{abstract}
Refractive surgery has been the second most common surgical procedure after cataract surgery in the eye health field in Indonesia. The projection of refractive disorder patients in Indonesia is about $4,6 \%$ of the population, according to the Indonesia's Ministry of Health data in 2011. Uncorrected refractive disorders can lead to blind. LASIK stands for LaserAssisted in situ Keratomileusis. It is a type of laser surgery to treat myopia, astigmatism and hyperopia. Myopia is a very common refractive error that people in general usually have. The prevalence rates of myopia are the highest in Asian countries, Indonesia is not excluded. Lasik procedure helps to correct the shape of the cornea, enabling light to be focused on the retina. The main reasons for people with eye refractive disorder do not seek Lasik surgery treatment are the expensive cost, fear of surgery and other unnecessary feelings. In addition to that, external factors such as the limitation of medical personnel and eye clinic facilities that can perform Lasik surgery also contribute to the still-low number of the patients undergo the procedure. By considering the analysis of business plan components to build Lasik eye health services that offers an effective treatment with a flexible payment scheme, this business model provides a promising return of investment (Rol). Significant gap between the number of people with refractive disorders and available eye care services with Lasik surgery equipped with experienced human resources and the latest technology opens the market for health care industry in Indonesia. The biggest challenge lies on medical cost. This new business model in eye clinic provides profitable gain both for investor and for obtaining Indonesia's Vision 2020. This article describes experience to develop and implement new business model in Lasik clinic in Jakarta to answer the medical cost challenges facing by the patients. The main goal is to encourage the nationwide replication to meet Indonesia's Vision 2020.
\end{abstract}

\section{KEY WORDS}

Lasik, refractive disorder, myopia, astigmatism, Lasik surgery, surgical cost.

Health, according to World Health Organization, can be interpreted as a well overall condition including physical, mental and social conditions, and not just the absence of a disease or disability. Healthy sight has been of one of global concerns and in 2003 World Health Assembly (56th WHA) has launched its resolution of "Elimination of Avoidable Blindness" by 2020 which has been signed by more than 40 countries which Indonesia Government is one of the signatories. Through this then comes up a program of Vision 2020: Right to Sight.

According to the Survey of the Sight and Hearing on 1993-1996 the number of national blindness in Indonesia reaches 1,5\%, the highest in Asia. Bangladesh 1\%, India 0,7\%, and Thailand counts for $0,3 \%$. If there is 12 of global population experiencing blindness every one hour it means four (4) of them contributed from countries in Southeast Asia which one (1) of them comes from Indonesia! Data from Indonesia's Ministry of Health shows that the causes of blindness are cataract $(0,78 \%)$, glaucoma $(0,12 \%)$, refractive disorders $(0,14 \%)$, and other causes-related to aging $(0,38 \%)$.

The refractive disorders are myopia, astigmatism and hyperopia. These refraction disorders can be overcome using eye glasses, contact lenses or Lasik surgery. Myopia is a very common refractive error that people in general usually have. The prevalence rates of 
myopia are the highest in Asian countries and the lowest in predominantly white populations such as the US and Europe.

Gazzard et al, reviewed that a study done in Sumatra, Indonesia, supported a hypothesis that suggested myopia was an increasing health problem in youngsters throughout Asia, including rural areas of Indonesia. (APBN). Some data show that $10 \%$ of Indonesia school-age children experience refractive disorders. Furthermore, myopia has a great impact on public health and socioeconomic well-being. Sight disturbance brings impact for productivity and mobility of the patients, family, society and state.

Though myopia is a common condition, the exact underlying causative mechanism remains unclear. It seems that both nature and nurture play important roles in the development of this common ocular disorder. Genetic factors have been emphasized in various studies. Because of rapidly increasing prevalence of myopia among school-age children, there is debate regarding whether the cause of myopia is due to genetic or environmental factors, such as frequent exposure to computer screens or handheld electronic devices and educational-load stress. These disorders can be corrected by using eye glasses, contact lenses, or undergoing LASIK surgery.

LASIK is Laser in-situ keratomileusis, a type of laser surgery used to treat myopia, hyperopia and astigmatism. This procedure helps to correct the shape of the cornea, enabling light to be focused onto the retina. This allows clearer vision while reducing or eliminating the need for glasses or contact lenses.

The availability of eye clinic with LASIK services across Indonesia faces some challenges which one of them, patients' affordability to pay the medical cost, will be discussed in this article. A new business model with payment scheme which helps patients to access the LASIK services described below has been implemented in Jakarta.

In the process of planning this new business model of eye clinic, several essential business planning components are incorporated as listed:

1. Description of the business;

2. Analyze the local market;

3. Competitive analysis;

4. Design development;

5. Marketing plan;

6. Operational plan;

7. Evaluate return on investment and expected revenue;

8. Management summary.

Understand that many people with refractive disorder cannot undergo Lasik surgery due to the expensive medical cost we develop a business plan to build Lasik eye health services which different from the existing eye clinics by changing the paradigm of Lasik eye health services: LASIK services is not always expensive and exclusive.

Based Indonesia's Ministry of Health data in 2011, the projection of refractive disorder patients is about $4,6 \%$ of the total population. The number of people with refractive disorders in West Jakarta, especially in high schools, is approximately 1778 children. On the other hand, in 2016, according to suppliers' information, there were only 3 well-known eye care services particularly in Lasik surgery service in Jakarta. There were 120 patients undergoing Lasik surgery a month and 1440 patients undergoing the same procedure in a year.

It shows there is a significant gap between the number of people with refractive disorders and the availability of eye care services with Lasik surgery. There are many people with refractive abnormalities, but there are limited eye care services of Lasik surgery in the community. It can be interpreted that providing services of Lasik surgery has great potentials and the business can continue to grow in line with technological advancements. So, business of Lasik surgery service has the opportunity to develop.

It is important to identify the target customers, assess the market size and the potential growth, and find ways minimizing weakness and maximizing the strengths as well as knowing the existing opportunities to deal with threats that may affect the existence of this business. The type of analysis used is Porter's five forces analysis and SWOT for analyzing the local market in Jakarta. 
SWOT analysis:

STRENGTHS

1. Offering a lower price with flexible payment options;

2. Accredited LASIK clinic;

3. Experienced and qualified human resources;

4. A good relationship with the suppliers;

5. Using the latest LASIK technology and equipment.

WEAKNESSES

1. Unlike the competitors, the clinic has not yet been recognized by the community;

2. No tangible assets;

3. No referral procedures yet;

4. LASIK surgery is not yet covered by the Indonesia's Government health insurance scheme (BPJS) and the private insurance.

OPPORTUNITIES

1. The number of LASIK services is insufficient compared to the number of patients with refractive disorders;

2. The number of qualified human resources who can perform LASIK surgery cannot fulfill the demand of LASIK services;

3. The awareness of eye care and appearance are improving;

4. Some careers such as in military, police department, modeling, sports, or being a pilot requires a good vision without spectacles;

5. Some patients do not feel comfortable wearing soft lens or spectacles.

THREATS

1. The improvement of LASIK technology and equipment grow rapidly;

2. Unstable surgical tools prior due the money exchange report;

3. The number of uneducated people with refractive disorders and the social culture are still significant factors that can burden LASIK surgery services;

4. Using spectacles and contact lenses are attractive options to replace the treatment of undergoing LASIK surgery;

5. The "medical tourism" trend.

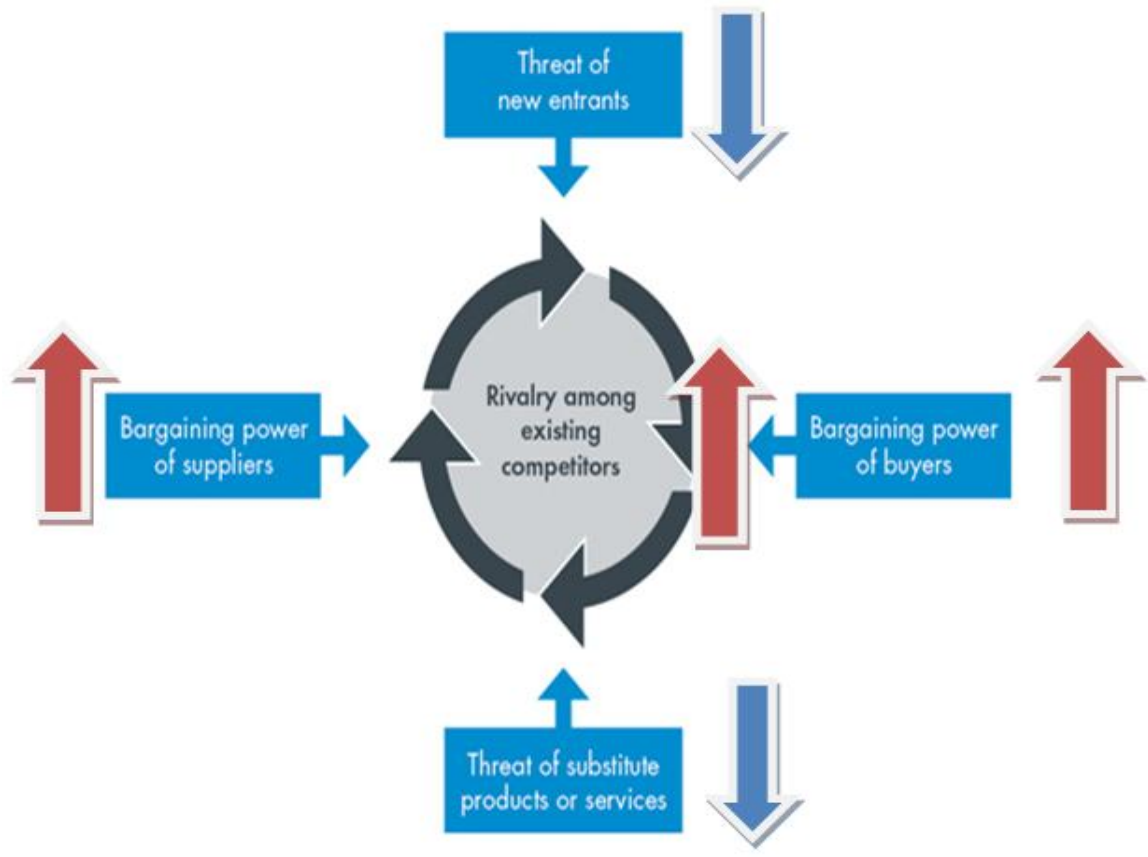

Figure 1 - Porter's Five Forces Analysis

The largest pressure sequence of the five force porter to the Lasik Center is threat of substitute products or services. Many people with refraction disorder do not undergo Lasik 
surgery due to expensive medical cost and feeling scare of the procedure. Choosing to wear eye glasses or contact lenses are still best options for the patients.

Another pressure sequence is bargaining power of health care services buyers. The customers have the bargaining power to choose which LASIK clinic they want to visit.

There is an intense rivalry among existing competitors since people in the community are already familiar with the existing LASIK clinics.

However, the pressure from bargaining power of suppliers is low because supplier will participate as the investor in this LASIK center.

Threats of new players are also still low because it takes a lot of investment to develop a LASIK center and, the most significant one, there are not many experienced human resources in LASIK business yet.

The substitute products to replace Lasik procedure such as eyeglasses or contact lenses are still the main choice for people with disorders refraction. The cheap price of eyeglasses is a deciding factor for most people to choose this product.

Ying-Feng Zheng et al showed that higher socioeconomic status (e.g, higher education and income level) was not associated with higher expenditure on myopia, suggesting a lack of association between income elasticity and demand for myopia correction. The younger age of onset of wearing glasses was the only significant factor that was associated with increased cost. This is expected, as adults with younger age of onset of wearing glasses have a longer duration of disease, and, thus, longer duration of treatment, such as changing the spectacle prescription on a regular basis. Refractive surgery is now the second most common surgical procedure after cataract surgery. (26) The direct medical cost of laser refractive surgery is SGD\$ 4891 per patient, seven times higher than the costs of refractive correction. Based on the assumption that patient who had undergone laser refractive surgery did not have to pay for refractive correction, Javitt and Chiang (28) found out that laser photorefractive keratectomy (US\$2000 for each eye) was financially equivalent to wearing daily-wear soft contact lenses for 10 years in the United States. In our cohort study, nevertheless $28,6 \%(2 / 7)$ of Lasik patients still had annual expenditure on spectacles for their distant vision.

Table 1 - Price comparison of LASIK product substitutes (2016)

\begin{tabular}{|c|c|c|}
\hline No. & Lasik replacement products & Price \\
\hline 1. & $\begin{array}{l}\text { Eyeglasses with National } \\
\text { Health Insurance (every } 2 \text { year) }\end{array}$ & $\begin{array}{ll}\text { Grade 3: } & \text { US\$ 12 } \\
\text { Grade 2: } & \text { US\$ 16 } \\
\text { Grade 1: } & \text { US\$ 23 }\end{array}$ \\
\hline 2. & $\begin{array}{l}\text { Eyeglasses without Insurance } \\
\text { (better than with insurance) }\end{array}$ & Start from US\$ 154 \\
\hline 3. & Contact lenses & Start from US\$ 35 every 6 month \\
\hline
\end{tabular}

The procedure of LASIK surgery is more costly compared to eyeglasses or contact lenses. Nevertheless, LASIK procedure is permanent, and the procedure doesn't need to be repeated; whereas the patients who choose to wear eyeglasses or contact lenses have to change them periodically.

Table 2 - Price Comparison of LASIK Procedure for 2 Eyes (2016)

\begin{tabular}{|l|l|l|}
\hline No. & Competitors & Price \\
\hline 1. & Competitor A & US\$ 2000 \\
\hline 2. & Competitor B & US\$ 2154 \\
\hline 3. & Competitor C & US\$ 2154 \\
\hline
\end{tabular}

The buyers (patients) have strong bargaining power because many people can choose any LASIK centers they desire. In Jakarta, there are 3 eye health services providing LASIK services. They should be taken into account. The main difference comparing to other LASIK eye health services is the price of LASIK procedure. 
The price of Lasik surgery offered will be below the competitor's price, with the installment program, about 1615 US\$.

The rivalry among existing competitors is quite intense because the brands have been well known by the people. Besides, the tendency of loyalty to visit the same doctors who conduct practices in those Clinics drives patients to undergo the LASIK surgery there.

The bargaining power of suppliers is still low. The supplier will participate as investor with agreement that all LASIK machines and consumables goods used for LASIK surgery will be provided with special prices.

The threat of new players is also insignificant since it requires a large amount of investment to establish one LASIK center. Furthermore, there is still limited amount of human resources who have skills and experience in LASIK surgery.

Some of the components of competitive analysis are: identifying the strengths, weaknesses, opportunities, threats, determining the financials etc. Aaker (1984) has proposed a model to rank the business against its competitors using the key success factors (KSF). Once the various conditions under KSF is decided they need to be graded, the weights allotted should some up to 1 . Once the weight has been allocated, the strength rating is allotted to each KSF ranging from 1 (weak) to 5 (strong). The calculation of the firm strength; the strength rating of the corresponding KSF is multiplied with weights parallel to it. The final rating denotes the overall strength. The higher the rating, the higher the overall strength is. With the reference to Table1, it is seen that entrepreneurs business have a middle rating and hence it is better than competitor $\mathrm{C}$.

Table 3 - Competitive Analysis

\begin{tabular}{|c|c|c|c|c|c|c|c|c|c|c|c|}
\hline \multirow[t]{2}{*}{\begin{tabular}{|l|} 
Key \\
Success \\
Factors
\end{tabular}} & \multirow[t]{2}{*}{ Weights } & \multicolumn{2}{|c|}{ Own business } & \multicolumn{2}{|c|}{$\begin{array}{l}\text { Competitor } \\
\text { A }\end{array}$} & \multicolumn{2}{|c|}{$\begin{array}{l}\text { Competitor } \\
\text { B }\end{array}$} & \multicolumn{2}{|c|}{ C Competitor } & \multicolumn{2}{|c|}{$\begin{array}{l}\text { Eyeglasses } \\
\text { or } \\
\text { Contact lens }\end{array}$} \\
\hline & & Rating & Weights & Rating & Weights & Rating & Weights & Rating & Weights & Rating & Weights \\
\hline $\begin{array}{l}\text { Brand } \\
\text { awareness }\end{array}$ & 0.20 & 3 & 0.6 & 4 & 0.8 & 4 & 0.8 & 3 & 0.6 & 4 & 0.8 \\
\hline Service & 0.20 & 3 & 0.6 & 4 & 0.8 & 3 & 0.6 & 3 & 0.6 & 4 & 0.8 \\
\hline \begin{tabular}{|l} 
Sales \\
turnover
\end{tabular} & 0.06 & 2 & 0.12 & 4 & 0.24 & 3 & 0.18 & 2 & 0.12 & 4 & 0.24 \\
\hline $\begin{array}{l}\text { Market } \\
\text { share }\end{array}$ & 0.09 & 4 & 0.36 & 3 & 0.27 & 3 & 0.27 & 2 & 0.18 & 4 & 0.36 \\
\hline $\begin{array}{l}\text { Business } \\
\text { experience }\end{array}$ & 0.06 & 2 & 0.12 & 4 & 0.24 & 3 & 0.18 & 2 & 0.12 & 2 & 0.12 \\
\hline $\begin{array}{l}\text { Financial } \\
\text { strength }\end{array}$ & 0.09 & 3 & 0.27 & 3 & 0.27 & 3 & 0.27 & 3 & 0.27 & 2 & 0.18 \\
\hline Location & 0.20 & 3 & 0.6 & 3 & 0.6 & 3 & 0.6 & 1 & 0.2 & 3 & 0.6 \\
\hline $\begin{array}{l}\text { Provision of } \\
\text { facilities }\end{array}$ & 0.10 & 4 & 0.4 & 4 & 0.4 & 3 & 0.3 & 3 & 0.3 & 2 & 0.2 \\
\hline TOTAL & 1.00 & & 3.07 & & 3.62 & & 3.2 & & 2.39 & & 3.3 \\
\hline
\end{tabular}

Design and development plans are needed to show the stages of product planning, graphs of development in the context of production and sales.

The LASIK business that will be built has a strong competitive position and high market growth, because it is in the competitive quadrant. The competitive strategy includes market development, market penetration, product development, backward integration, forward integration, horizontal integration and related diversifications.

The market penetration is implemented by conducting continuous promotion and offering the affordable price of Lasik surgery, and flexible payment terms.

In this segment, the strategies are formed to decide how to reach the customers, how to capture the attention of the potential customers, what kind the massages needed to get a response motivating the potential customer to come and get LASIK services that s/he wants. Since the marketing plan is associated with costs, it is essential to select the methods that 
give a higher impact. The methods can include paid advertisement using social media, sales promotion, personal sales, magazine and radio to promote this LASIK eye health service that offers an effective and flexible payment scheme with well-experienced human resources in LASIK surgery and the use of state-of the art LASIK equipment.

The operational plan will focus on the logistics needed by the clinic such as various tasks and responsibilities of the management team, how the inter-departmental assignment procedures established in the clinic, as well as budget and expenditure requirements related to the clinic's operations.

Operational Plan:

1. Business establishment preparation planning;

2. Location and clinic lay-out planning;

3. Medical devices planning;

4. Consumable items planning;

5. Patient flow planning.

The financial plan is the main section of the business plan as it integrates all parts of the business, namely: the marketing plan, operational plan, and other details including the expected financial outcomes.

Table 4 - Capital Need and Usage

\begin{tabular}{|l|l|l|}
\hline Funding & Estimation & Actual \\
\hline Investor funds & & \\
Investor & US\$ 784.615 & - \\
Supplier & US\$ 192.308 & - \\
Owner of the office & US\$ 38.462 & - \\
Total Investment & US\$ 1.015.385 & - \\
\hline Loan & - & \\
\hline Other Funding & - & \\
\hline Total Funding & US\$ 1.015.385 & - \\
\hline Cost & Estimation & Actual \\
\hline Pre-investment & US\$ 2.846 & - \\
\hline Office rent & US\$ 15.385 & - \\
\hline $\begin{array}{l}\text { Initial investment: Lasik machine and } \\
\text { support devices, office tools, application of } \\
\text { IT and office renovation }\end{array}$ & US 619.231 & - \\
\hline
\end{tabular}

\begin{tabular}{|l|l|l|}
\hline $\begin{array}{l}\text { Working capital: consumable items, } \\
\text { employee salary, overhead cost, marketing } \\
\text { cost }\end{array}$ & & - \\
\hline Total Cost & US\$ 1.010 .539 & \\
\hline Surplus/(deficit) & US\$ 4.846 & - \\
\hline
\end{tabular}

The estimated revenue is calculated from the expected sale volume and the target price. In calculating the projected revenue and sales, the sensitivity analysis is used to understand more about how far the financial analysis is able to confront the changing factors that influence it.

The sensitivity analysis is carried out by creating 3 revenue recognitions: 1 . Pessimist $=$ $6 \% ; 2$. Normal $=8 \% ; 3$. Optimist $=10 \%$.

Table 5 - The Calculation of the Number of Patients Based on the Target Market

\begin{tabular}{|c|c|c|}
\hline Assumption & Annual Surgery Performed & Annual Consultation Performed \\
\hline Pessimist & 541 & 1805 \\
\hline Normal & 576 & 1920 \\
\hline Optimist & 634 & 2112 \\
\hline
\end{tabular}


Table 6 - After-tax Income Yearly Budget

\begin{tabular}{|c|c|c|c|}
\hline Services & Pessimist & Normal & Optimist \\
\hline Consultation & US\$124.962 & US\$132.923 & US\$146.215 \\
\hline Surgery & US\$794.475 & US\$ 845.874 & US\$ 931.048 \\
\hline TOTAL & US\$ 919.437 & US\$ 978.797 & US\$1.077.263 \\
\hline
\end{tabular}

The payment of dividends will be distributed at the end of the third year as much as $80 \%$ of the net profit of the third year after the tax, and the rest will become the retained earnings that will be used to fund the expansion plan in the next 4 to 5 years. In addition, the payment of the dividends is also to give the investors the flexibility making use of the profit of this business.

Table 7 - Projected Retained Earnings and Dividends Each Year (normal condition)

\begin{tabular}{|c|c|c|c|c|c|}
\hline $\mathrm{n} / \mathrm{n}$ & 1 & 2 & 3 & 4 & 5 \\
\hline Retained earnings (US\$) & - & 283.799 & 668.018 & 789.689 & 971.994 \\
\hline Net Profit (US\$) & 283.799 & 384.218 & 608.355 & 911.528 & 1.454 .159 \\
\hline Dividends (US\$) & - & - & $(486.68)$ & $(729,22)$ & $(1.163 .32)$ \\
\hline Final Retained Earnings (US\$) & 283.799 & 668.017 & 789.689 & 882.172 & 1.262 .826 \\
\hline
\end{tabular}

Return on Investment Ratio is ratio that calculates the profits of company in producing the income statement of the stakeholders.

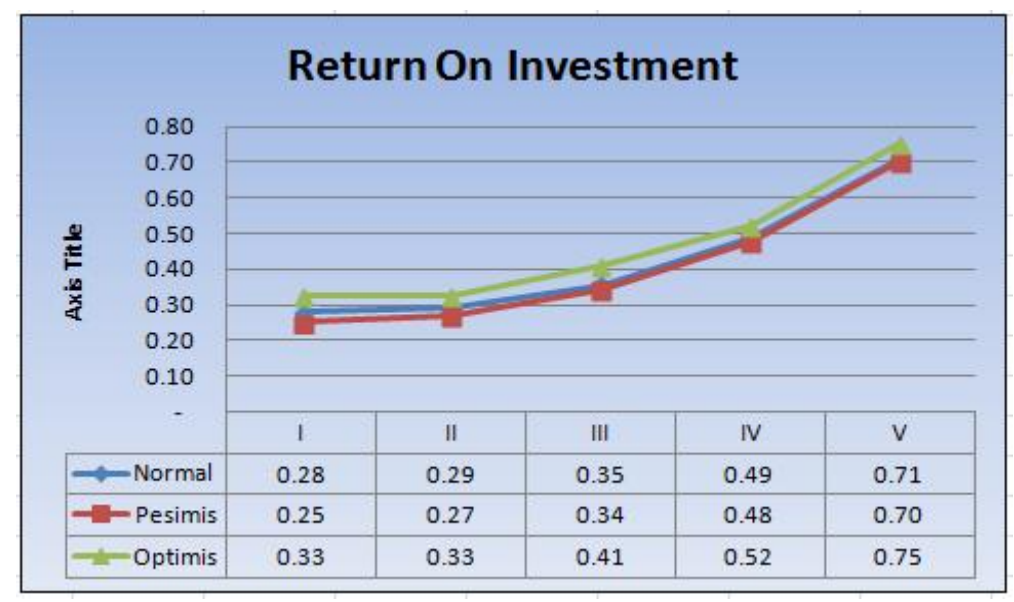

Figure 2 - Trend of Return on Investment Ratio

Source of funds comes from 3 investors, one of which is the distributor of LASIK machine. In order to be more efficient, this new business model of LASIK eye clinic works with the existing eye clinics that do not provide LASIK services.

Another factor that influences finding is the people who are associated with the business. It should include details as follow:

1. The prior experience of the team members;

2. Their achievements;

3. Reputation within the business surroundings;

4. Their knowledge, skills and abilities;

5. Commitment towards the set-up;

6. The strengths of the team as a whole;

7. The team's viewpoint.

The strength of this LASIK business model lies on its human resources who are experienced and qualified and with good reputation in the business. 


\section{CONCLUSION}

With all the considerations of the analysis component business plan to build LASIK eye health service that offers an effective and a flexible cost, with experienced human resources in LASIK procedures, use LASIK machine with state-of the art technology, this business will have the opportunity to develop quickly in order to meet the needs of patients with refractive disorders.

The potential market for this New Business Model is wide-open. The next challenge of how to use BPJS-scheme for Lasik procedure should be analyzed further in order to achieve Indonesia's goal on Vision 2020.

\section{REFERENCES}

1. Aaker, D., (1984), "how to select a Business Strategy". California Management Review, Vol.XXVI, No.3.

2. Abimanju, Ariadi. 2015. Marketing Book For Those Who Don't Like To Read, Jakarta.

3. Ahmad Rodoni, 2014. Manajemen Keuangan Modern. Penerbit Mitra Wacana Media, Jakarta.

4. Ashwin J. Baliga, Dr. Lewlyn L. R. Rodrigues, (2015), "Business Plan - The Secret to Success", The International Journal of Bisnis and Management, Vol. 3 Iss pp.210-214.

5. Cyr, L. (2007). Creating a Business Plan. Boston, Massachusetts: Harvard Business School Press.

6. David, Fred., (2007). Strategic Management: Concept and Cases International Version. Pearson Higher Education.

7. Definisi sehat menurut WHO. http://kekeanisa20091995.wordpress.com.

8. Dinas Kesehatan Provinsi DKI Jakarta. 2016. Kesehatan Mata Di Provinsi DKI Jakarta. Program PTM Dinkesprov DKI Jakarta.

9. Friend,G., Zehle,S. 2004. Guide to Bussines Planning. The Economist. Italy.

10. Gus Gazzard, Seang-Mei Saw, David Koh, et al. Refractive Error in Sumatra, IndonesiaA population- Based Prevalence Study. APBN 2002; Vol 6 No.2:49-52.

11. Harvard Bussines Study, Case Interview Guide, eBook.

12. John Maleyeff. (2007), Improving service Delivery in Government with Lean Six Sigma. IBM Center for Business of Government.

13. Kementerian Kesehatan Republik Indonesia, 2014. Profil Kesehatan Indonesia Tahun 2013, Jakarta.

14. Kotler,P., Keller, K.L., 2007, Manajemen Pemasaran. Edisi 12 Bahasa Indonesia, PT. Indeks, Jakarta.

15. Pei-Chang Wu, Hsiu-Mei Huang, Hun-Ju Yu, et al. Epidemiology of Myopia. Asia Pac J Ophthalmol 2016;5:386-393.

16. Roger Beuerman. Molecular Biology of Myopia. APBN 2002;Vol.6 No 2:43-48.

17. Tjiptono, Fandy. 2015. Strategi Pemasaran. Edisi Keempat, Andi Offset, Yogyakarta.

18. Wirawan, Dr., MSL., Sp.A.,M.M.,M.Si., Kepemipinan Teori, Psikologi,Hukum Ketenagakerjaan, Aplikasi dan Penelitian, Aplikasi dalam Organisasi Bisnis, Pemerintahan dan Pendidikan. Divisi Buku Perguruan Tinggi. PT Raja Grafindo Persada. Jakarta: Rajawali Pers, Maret 2015.

19. Ying-Feng Zheng, Chen-Wei Pan, Junxing Chay, et al. The Economic Cost of Myopia in Adults aged Over 40 Years in Singapore. Invest Ophthalmol Vis Sci 2013; 54:7532-7537. 